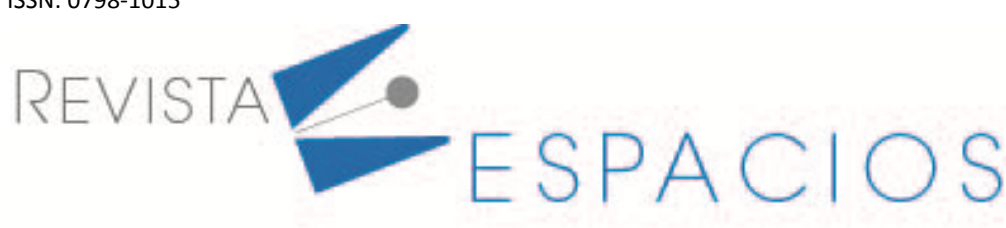

\title{
Evaluation of the use of role play in financial accounting
}

\section{Evaluación del uso de juego de rol en contabilidad financiera}

\author{
RAMÓN-DANGLA, Remedios ${ }^{1}$ \\ RICO GÓMEZ, María L. ${ }^{2}$ \\ PONCE GEA, Ana I. ${ }^{3}$
}

\begin{abstract}
The role play is presented in Higher Education as an alternative that fosters constructive learning, cooperation among equals and motivation for learning. In this study, we set ourselves the objective of determining the effects of the application of a role play in the subject of Financial Accounting in the Tourism Degree. According to the analysis, we can conclude that the role-playing game brings benefits for the students in relation to satisfaction and academic achievement.

Key words: higher education, teaching methods, activity learning, role play.

Resumen

El juego de rol se presenta, en Educación Superior, como una alternativa favorecedora del aprendizaje constructivo, la cooperación entre iguales y la motivación por el aprendizaje. En este estudio nos planteamos como objetivo determinar los efectos de la aplicación de un juego de rol en la asignatura de Contabilidad Financiera del Grado de Turismo. De acuerdo con el análisis, concluimos que la aplicación del juego de rol conlleva beneficios para el alumnado en relación con su satisfacción y rendimiento académico.

Palabras clave: educación superior, métodos de enseñanza, aprendizaje activo, role play.
\end{abstract}

\section{Introduction}

In a society framed by globalization and the impact of new technologies, the notion of a new self-entrepreneur, critical, communicative, versatile, developer-of-skills-and-values citizen and professional acquires importance.

From the convergence in the European Higher Education Area (EHEA) in order to achieve effective learning adapted to the characteristics of the new social order, critical, creative and autonomous training is emphasized. This directly implies a change in the relationship between teacher and student in the teaching-learning process. It is understood that the way of learning is through a constant personal search, where the mere transmission of knowledge no longer has a place, but rather learning by doing, experimenting, in continuous harmony with life, providing students with all the working mechanisms that bring them closer to the interpretation, creation and management of knowledge (Inda et al., 2008). This objective is emphasized with the presence of information and communication technologies and the virtual-net generation, which has changed the traditional way of understanding the acquisition of knowledge (Prensky, 2001).

\footnotetext{
${ }^{1}$ Lecturer in Department of Financial Economics and Accounting. University of Alicante. remedios.ramon@ua.es

${ }^{2}$ Lecturer in Deparment of General and Specific Didactics. University of Alicante. marialuisa.rico@ua.es

${ }^{3}$ Lecturer in Deparment of General and Specific Didactics. University of Alicante. anaisabel.ponce@ua.es
} 
In this sense, there is an agreement (Marcelo et al., 2015) that the most appropriate didactic methodologies and, therefore, towards which the EHEA should converge, should be based on simulations as close as possible to reality, in which the student acquires an active role. Hence, games are the ideal environment for learning: they allow learning from mistakes, stimulate critical thinking and provide students with a sense of control over their learning (Kapp, 2012). Game-based learning facilitates the acquisition of competencies and skills such as collaboration, the interpretation of what happens around, the solving of problems or communication, which in short is a staging close to real-life (Johnson et al., 2014).

In higher education, the use of simulation games, around which we articulate our research, is still relatively new. However, there are recent empirical studies that show its suitability (Barrera et al., 2020; Kalleci \& Aksoy, 2020; Moreno-Guerrero et al., 2020; Oberle et al., 2020), some of them linked to the field of economics and business (Normando et al., 2020; Thanasi-Boçe, 2020). Despite this, in the Spanish case and from the perspective of management or analytical accounting, we only have the studies of Escobar and Lobo (2005) and Calador et al. (2018) who, despite their temporal distance, agree that role play encourages teamwork, leadership, creativity, as well as some interpersonal and systemic competencies. However, if studies from the perspective of management accounting are scarce, they are even scarcer from financial accounting where we only found one study (Ros \& Conesa, 2013) that confirms that role play is useful for the acquisition of both general and specific competencies and all the more, the more participatory and closer to reality the adopted methodology is.

Therefore, it is necessary to know a greater volume of experiences that confirms the theoretical hypotheses about the properties of the game, its characteristics, or its effectiveness on learning outcomes (Clark et al., 2016).

Hence, the aim of this work: to delimit the implications of the application of a role play in the subject of Financial Accounting in the Tourism Degree, in relation to the academic achievement of the students and their satisfaction with the teaching methodology.

Before describing the empirical research developed, and to interpret the results, we made a synthesis of the previous literature.

The new educational objectives are today in accordance with the constructivist paradigm in its sociocultural aspect (Yatnitsky et al., 2016) and, above all, with Bruner's discovery-based learning (Bruner, 1969). We are dealing, in essence, with active learning methods, where learning is significant as it occurs in interaction with the space and the rest of the subjects in situations of active and realistic participation, from whose experience their knowledge and comprehensive personal development are reformulated and built. What is important is how, in real learning situations, students are significantly, cognitively and emotionally involved with the rest to carry out the task, generating and acquiring new knowledge in an active process of analysis, reflection and discussion (Johnson et al., 2013). This is in line with the idea of cooperative learning, since cooperation implies an exercise in behavioural, attitudinal and cognitive commitment to achieve the goal as a group (Johnson \& Johnson, 2018).

Analysis, reflection, understanding, initiative, creativity and autonomy skills are developed through a constructive controversy produced by the exchange of ideas and participation among the subjects. Also, social values such as tolerance, empathy or respect (Abella \& Grande, 2010). In turn, the effects of social interaction itself generate a positive, emotional and cognitive interdependence, since the benefit depends on the work of the rest and conversely, on mutual rewards, under the development of personal responsibility and autonomy, as well as group processing capacity. All these skills are necessary for the current socio-professional environment, which are built by discovering and transforming cognitive structures in participatory experiential situations (Johnson et al., 2014).

As defined by Schützenberger (1979), the objective of role play is to learn and learn to learn, with effects on an emotional, cognitive and holistic level. Motivation is one of the most significant perspectives because it 
stimulates the individuals to reflect (Ferrer et al., 2020) and, the use of role play in the teaching process increases intrinsic motivation in students (Wouters et al., 2013). Indeed, in role play, as the individuals participate in simulated contexts of real situations, learning by doing, they feel involved in decision-making throughout their experiential learning, the result of which is the formation of the subject to individual and social scale (Marcelo et al., 2015). Learning in problem solving, in real situations, within an environment of reciprocity, cooperation and respect, trains individuals in the following: affective-emotional-relational (relationships-interactions to live and work with others), cognitive (analyse, abstract, organize, manage and use of information to build new knowledge according to a specific environment) and professional (planning, prediction, creativity, adaptability, etc.) competencies (Ortiz, 2015). With this pedagogical approach, not only knowledge is learned and built, but also attitudes and competencies are moulded to apply the instruments in the situational context, in addition to improving social and team skills and interactions (Muñoz \& Huser, 2008). Furthermore, experiential learning in simulated situations of the professional world favours the preparation for the socio-labour insertion, improves the formative transition to the socio-professional life, turning education into the preparatory path for the labour market, for the improvement of employability (Niemeyer, 2004).

In this way, recreating situations related to the real world increases motivation for discipline, learning in interaction with the rest of the members, assuming the commitment and responsibility for success and failure (De Urbina et al., 2010; Morales and Villa, 2019). This socialisation, which entails joint decision-making with the previous step of what the decisive discovery implies, internalises what has been learned through the development of personal freedom and autonomy within teamwork. Therefore, it is not possible to confuse the simulation game or role play with gamification, because whereas in the former the purpose is learning, the latter focuses on the incentive of behaviours through the playful technique of the game (Urquidi \& Calabor, 2014); the priority is to create a predisposition towards meaningful learning that interprets reality, develops instrumental capacities and configures values such as responsibility, commitment and self-esteem (Abella \& Grande, 2010).

With this technique, the role of the teacher changes. It focuses on the design of the game instructions and the learning situation to be simulated, provides all the information and defines the tasks to be carried out, to develop the proposed competence objective (Zumaquero, 2018). Indeed, apart from mastering a discipline, they must have the ability to create active learning environments, based on problems, that enhance the interest, autonomous, inventive and creative capacity of students (Santiago \& Fonseca, 2016). The teacher must reinforce the work of constructive discussion, problem solving in a shared space, to reach the convergence of ideas, in an environment of freedom, dialogue and respect (McCrudden et al., 2010). And, with all this, teacher perform competencies that enhance the horizontal and two-way relationship with the students in concrete and real learning situations, in the socio-constructivist sense, against the traditional and authoritarian vision of the teacher: relationships of respect, empathy, and understanding and attention to students are established, based on fair exchanges and mutual benefits and responsibilities (Cerdá \& Ramírez, 2010; Galvis, 2007).

To apply the simulation games to the subject of Accounting in the Tourism Degree, this approach is adapted to the competency objectives of the tourism sector: professional profiles based on the training of managers and business leaders, responsibility, decision-making, resolution of problems, cooperation, autonomy, creativity or leadership as well as in the participation of various economic and social activities that require different training and professional competencies around tourism in a multidisciplinary and cross-functional manner (Agencia Nacional de Evaluación de la Calidad y Acreditación, 2004). As established by the definition of Hacer (1960), which relates the role play to the exercise to be carried out in a company, they are simplified mathematical abstractions of a simulated situation and linked to the business environment that allow, individually or in groups, to run a company, making decisions about the operations to be developed. 
The purpose of the accounting subject is to achieve the effectiveness of the exercise of learning to learn to apply it to the professional world: to promote attitudes of analysis, reflection, understanding, organization, information planning, through open group discussion, to intervene in the problem solving, using communication, interaction and teamwork strategies with a constructive criticism. Indeed, role playing, applied to this educational context, prepares these competencies, recreating business situations, capable of developing adaptation to new and future situations for the purpose of socio-professional improvement and effectiveness, typical of the degree (Marcelo et al., 2015). As the work of Escobar and Lobo (2005) well explains, applying the role play or simulation to hotel management, in the subject of Management Accounting in Higher Education, this technique favours the interrelation of the acquired knowledge and decision-making capacities, communication and teamwork through the development of: instrumental skills, combining cognitive and methodological skills; individual interpersonal skills, collaboration in common goals, and social skills, as a team; and systemic competencies, linking understanding, sensitivity and knowledge (Mora et al., 2018). That is, to be trained in experiential experience, through a sense of belonging to improve opportunities for training and work socialisation. Thus, the hypothesis used in this work coincides with these studies: role-playing increases the motivation of students for the Accounting subject in the Tourism Degree and improves their training and professional skills. Hence, the objective is to compare the results produced in learning in students exposed and not exposed to the pedagogical technique and to characterise the perception of satisfaction of the students who used constructive and cooperative learning, through the simulation of the closest situations to the socioprofessional reality.

In the same vein, we specify the general objective of the investigation and its specific objectives as follows:

G.O.1: To determine the effects of the application of a role play in the Financial Accounting subject in the Tourism Degree.

S.O.1.: To describe the degree of satisfaction with the application of the role-playing game, comparing the different groups according to age and gender.

S.O.2.: To compare the academic achievement of students belonging to groups where the role-playing method has been implemented and groups where traditional methodological strategies have been used.

\section{Methodology}

\subsection{Description of the subject and the participants}

The participants in the research were 107 students enrolled in the Accounting subject of the second year of Tourism in the 2019/20 academic year, divided into an experimental group $(n=29)$ and a control group $(n=78)$. According to the data collected, our sample is made up of $29.99 \%$ men and $70.01 \%$ women, which is in line with the usual enrolment of this degree where there is one man for every three women. Regarding age and in accordance to the subsequent analysis, they are divided into four groups as follows: E1, Students aged less than or equal to 20 years (41.17\%); E2, Students aged $21-22$ years (23.52\%); E3, Students aged $23-24$ years (5.89\%); and E4, Students aged 25 and over (29.42\%).

Regarding the subject, it is a compulsory semester subject that has a workload for the student equivalent to 6 ECTS (European Credits Transfer and Accumulation Systems) credits spread over 40 hours of theoretical class and 20 hours of practice.

A professional graduated in Tourism usually occupies management positions in companies or organisations related to the tourism sector, so they usually must make decisions based on accounting information. For this 
reason, the objective of the course is for students to master accounting terminology and learn about the process of capturing, valuing and recording the financial information of companies.

The accounting information issued by companies is prepared, synthesized, standardized, systematized and transmitted through Financial Accounting which, supported by other disciplines, allows showing to the various economic agents a minimum common denominator with useful information for decision-making (García, 2009). That is why in this subject the basic knowledge of Accounting is taught, its fundamental objective being the theoretical-practical learning of Financial Accounting, which enables the student to understand, prepare and transmit accounting information oriented to the taking of management decisions in companies.

The teaching guide for the subject establishes the competencies to be acquired by the students, among which we highlight the ability to "analyse, synthesize and account for the economic and patrimonial information of organizations." Those students can know and understand the language of business. In this sense, learning to prepare in a synthesized, homogenized and systematized way the financial information of the company will allow the graduate in Tourism to reach the specific competencies and will contribute to the development of reflective, scientific and social skills.

\subsection{Design of the research}

For the development of the experience, a quasi-experimental randomized controlled design was used (Table 1), with the random distribution of the students between the control and experimental groups, respecting the nature of the groups. Subsequently, the group of students who were going to carry out the experience formed pairs on a voluntary basis.

Table 1

Distribution of the experience by groups

\begin{tabular}{|c|c|c|c|c|}
\hline Group & $\mathbf{n}$ & Pretest & Treatment & Posttest \\
\hline Control & 78 & $\mathrm{O}_{1}$ & & $\mathrm{O}_{2}$ \\
\hline Experimental & 29 & $\mathrm{O}_{1}$ & $\mathrm{X}$ & $\mathrm{O}_{2}$ \\
\hline
\end{tabular}

Source: Prepared by authors

Under this design, the treatment -in this case, the teaching method- that was applied to the experimental group was role-playing during four weeks of the course (it was necessary to have extensive knowledge of the subject in order to be able to carry it out), keeping the traditionally used methodology in the control group. That is, the control group developed the activity as a traditional accounting assumption in which, through a text, different economic facts were enunciated. For the specific work on the content, all the students in the control group were given a transcript of a commercial invoice: the same one that was physically delivered to the experimental group. In the text, the usual commercial traffic operations in companies in the tourism sector were described and it was necessary, with the knowledge acquired by the individual, to assess and account for the facts described.

On the other hand, the role play consisted of recreating the same economic facts, presented by means of the same merchandise purchase-sale invoice and its accounting record, but, in the case of the experimental group, the economic facts were presented with the commercial document instead of transcribing them.

Any exchange of merchandise is associated, on the one hand, with an agent that makes a purchase, but symmetrically, there is an agent who sells. Thus, before an invoice for a purchase from a company, two different agents will appear: the buyer, who will enjoy certain rights, but will also acquire certain obligations and, for the same economic events, with symmetrical rights and obligations, the seller will appear.

In a first session, the students were informed of the characteristics to be considered for the game and the roles of buyer and seller were distributed on a random basis. Then, the commercial document object of the practice 
was made available to them: the invoice of a tourist establishment in which twenty-eight commercial events appeared to represent accounting: purchase of merchandise, discounts, containers and packaging with the right to return, VAT tax, etc.

The distribution of the accounting representation of the different economic events between the teams was again randomised for each of the two roles. In other words, all the pairs that in the first draw had drawn "B" (buyer role) now had to draw, from another ballot box, a new ballot that would designate the number of the economic events that they would have to represent in accounting terms. There were fourteen ballots in ballot box "B" and each ballot had two correlative numbers that referred to the line of the invoice. Thus, for example, the ballot containing (1-2) referred to economic events one and two of the invoice. The total number of ballot papers contained in the ballot box was (1-2); (3-4); (5-6); (7-8); (9-10); (11-12); (13-14); (15-16); (17-18); (19-20); (21-22) (23-24); (25-26) (27-28).

There was also a "S" ballot box containing exactly the same ballots distributing the same economic facts, but in this case, for the teams that were to represent the role of the seller.

Each team representative of the "buyer" role would take a ballot paper from its "S" ballot box and the same, but from its corresponding ballot box, for the pair representatives of the "seller" role. In this way, each team had to represent two economic facts in accounting terms, and each economic fact was to be represented from its two accounting aspects.

On this way, students, individually and independently, had to try to record all the operations described in the published commercial document. While they were making the accounting entries of the different economic events, the groups could not be related to each other and they were supervised by the teacher. Subsequently, each group publicly presented the accounting records of each of the economic events that they had to represent and discussed with the rest of the students, the reasons why an event had been recorded in one way or another.

On the contrary, the control group had received a statement in which the same economic facts of the invoice were described, but without the actual commercial document. In this case, although it was also necessary to represent the events described from the perspective of the buyer and seller for accounting purposes, each student had to do so individually.

\subsection{Instruments and procedure}

The collection of information has been carried out through two information collection instruments, securing confidentiality and the informed consent of participants. These instruments are associated respectively to each of the specific research objectives set.

In relation to the first objective, to know the degree of satisfaction of the students with the teaching experience, a validated questionnaire was used, applied exclusively to the experimental group. Participants answered voluntary and they knew that results could be used in publications related to didactical methodology.

The questionnaire consists of two thematic blocks. The first of them refers to the socio-demographic data of the participating students: Gender (Male / Female) and age, under the four groupings described in the participants section (E1, E2, E3 and E4).

The second section or block consists of 22 items to study the degree of satisfaction of the students with the experience, based on the Likert scale of 1 to 5 , where 1 is totally in disagreement and 5 is totally in agreement.

The items are grouped into four dimensions, according to the analysis carried out to determine the construct of the instrument, defining the construct "Student satisfaction (S)". For this, an analysis of main components has 
been performed, with the aim of reducing the number of independent factors that may have explanatory power in the degree of student satisfaction and that, at the same time, collect all the available information (Bollen, 1989; Jolliffe, 2002). Thus, through factor analysis of the 22 items of the questionnaire and the orthogonal rotation of the correlation matrix, the independent variables can be grouped into four factors that explain four characteristics to describe the degree of student satisfaction. Factor extraction was performed following the Kaiser-Guttman rule by which those factors that showed eigenvalues greater than 1 in the rotated matrix were chosen. With the 4 new factors, $82.96 \%$ of the original data grouped together are explained (Table 2).

Table 2

Total variance explained

\begin{tabular}{|c|c|c|c|}
\hline \multirow{2}{*}{ Component } & \multicolumn{3}{|c|}{ Initial eigenvalues } \\
\cline { 2 - 4 } & Total & \% variance & \% accumulated \\
\hline 1 (Situated Learning) (SiL) & 13.161 & 59.821 & 59.821 \\
\hline 2 (Self-learning) (SeL) & 2.330 & 10.593 & 70.413 \\
\hline 3 (Didactic Strategies) (DS) & 1.676 & 7.618 & 78.032 \\
\hline 4 (Vocational Training) (VT) & 1.085 & 4.930 & 82.962 \\
\hline
\end{tabular}

Source: Prepared by authors

Each factor can be understood as a new variable obtained by combining the original variables in a certain way and is expressed as follows:

$X_{j}=\theta_{1 j} Z_{1 j}+\cdots+\theta_{k j} Z_{k j}$

Where

$\mathrm{j}=$ Component. $\ln$ our case $\mathrm{j}=(1 \ldots, 4)$.

$\mathrm{X}_{\mathrm{j}}=$ Value taken by each observation in component $\mathrm{j}$

$\theta_{\mathrm{kj}}=$ Coefficient of variable $\mathrm{k}$ in component $\mathrm{j}$

$\mathrm{Zkj}=$ Value taken by each observation in component $\mathrm{k}$

Each $\Theta \mathrm{kj}$ coefficient is obtained from the principal component analysis carried out applying the statistical program SPSS26, where the linear combination is normalized since it is satisfied that:

$\sum_{j=1}^{p} \theta_{1 j}^{2}$

For each of the factors, its internal consistency or reliability has been verified by means of an $\alpha$-Cronbach greater than 0.60 and its construct validity, since all the factors fulfil the Bartlett's sphericity assumption $(p<0.05)$ : the degree of correlation of the variables is very high and, therefore, it meets the condition of applying factor analysis and the Kaiser-Meyer-Oklin index (KMO) greater than 0.50 (Table 2)

In relation to the second specific research objective, and acting as a pre-test and post-test instrument, a written and objective test-type evaluation test has been used. This test is made up of twenty questions, with four possible options and only one correct, whose grade is based on a proportion of three wrongly answered questions shall subtract one correctly answered. The score for each exercise ranged from zero to ten, where five was the minimum passing score, with each item contributing an equal percentage to the configuration of the final grade. The contents and the evaluation method in pretest and post-test are identical, varying the 
formulation of the items between them to avoid the response by repetition / memory, but maintaining the scale proposed in the pretest to allow the comparison of results. Specifically, the skills measured as part of the "Academic Achievement (AA)" have been the economic valuation and accounting representation of the economic facts that are described in relation to the skills related to the purchase of merchandise, discounts, containers and packaging with right to refund and VAT tax, among others of a similar nature; coinciding with assumptions similar to those described in the role play. That is, valuation and accounting representation of commercial traffic operations since Accounting in the Tourism Degree is an introductory subject, its content is basically limited to this type of operations.

\subsection{Information analysis: variables and analytical procedures}

\subsubsection{Hypothesis testing, ANOVA and Regression}

In relation to the first specific objective and the construct "Student satisfaction (S)", its four factors obtained through factor analysis (SiL, SeL, DS and VT) have been analysed by means of a bilateral hypothesis test and with a confidence interval of $95 \%$. Through the $\mathrm{F}$ statistic and the $\mathrm{p}$-value in the Anova test, we have verified whether there have been significant differences in the degree of satisfaction of the students between sexes and age groups, having previously verified that they complied with the normality and homogeneity of the variances using a Levene statistic with a (sig> 0.05) for all factors or components. In addition, we try to know the contribution of each factor on student satisfaction, using a dependency model based on Multiple Linear Regressions (MLR), where the dependent variable is Satisfaction (Si) and the independent variables are the explanatory factors of the degree of satisfaction.

Thus, the RLM model was defined by equation (1)

$S_{i}=\alpha+\beta_{1} A S_{i j}+\beta_{2} A A_{i j}+\beta_{3} E D_{i j}+\beta_{4} F P_{i j}+\varepsilon$

Where:

$S_{i}$ is the degree of satisfaction of each student

$\alpha$ is a constant and $\varepsilon$ is the random disturbance.

Each $\beta$ represents the relative weight that each of the factors has in explaining the degree of student satisfaction with the experience with a 95\% confidence interval (Pérez and Santín 2008), with a being a constant.

The method used to approximate the model (RLM) was the "stepwise backward" method. In this method, all the variables are introduced into the equation and then they are excluded one after the other as long as they satisfy the elimination criterion based on the low partial correlation with the dependent variable. The model was developed using SPSS26, after verifying that, on the one hand, the hypotheses of normality of the error term and linearity of the response variable were fulfilled compared to the predictive ones, and that, on the other hand, the model offered high power explanatory represented by an "R-square" and "corrected R-box" of 0.56 and a Durbin-Watson statistic of 2.41 that indicates that the residuals are independent. From the adjustment of the linear regression we have been able to approximate which are the factors that have the greatest incidence on the degree of satisfaction of each student.

\subsubsection{General Linear Model}

For the analysis of quantitative data: "Academic Achievement (AA)" was used an Anova analysis of variance model with repeated means (MR-ANOVA) with a 95\% confidence interval, as it is the most appropriate method to study the effect of one or more factors when at least one of them is an intra-subject factor (Lindquist 1953). In our specific case, we used repeated measures for two factors (an intra factor and an inter factor). The grades 
of the students taken before and after performing the role play is the within-subject factor because all the subjects of the experience were exposed to both evaluation tests and the type of group (role or non-role) is the between-subject factor because they are groups of subjects who have received different experiences.

By means of the Box test, the homogeneity of the variances between the groups (Sig $=0.65$ ) was verified and, having only one within factor and another between, it was not necessary to consider the test of independence of the observations or Mauchly's sphericity.

Through the $\mathrm{F}$ statistic and the $\mathrm{p}$-value in the multivariate test, it was possible to compare if there was a difference in the means of the pre and post activity scores and if the interaction with the control group had an effect. From the within-subjects contrast test, the existence of inter-relationship between groups can be verified: the teaching experience had influenced the students' qualifications.

\section{Results}

In the following, we describe the results taking the specific delimited objectives as an axis.

\subsection{Students' satisfaction level}

On the one hand, paying attention to the descriptive analysis of the variable "Student satisfaction (S)" (Table 3), it can be observed that, on average, the student body is satisfied or quite satisfied with the contribution of the role play for each one of the established dimensions, highlighting in a special way the scores obtained for the factor "Didactic strategies (DS)", above 4, in both sexes and in three of the four age groups. Therefore, the evaluation of the aspects that have to do with its consideration as a didactic strategy is influenced (close relationship with the teacher, complementarity with other methods, etc.). On the other hand, the factor with the lowest means is that of "Self-learning (SeL)", which includes aspects such as ICT competence, reflection and evaluation activities, or the application of knowledge to the real professional situation, among others. Although it is not reflected in the table, it is extracted as an implicit result of the internal study of the factors that more than $65 \%$ of the students consider that the experience has allowed them to put into practice many of their acquired knowledge and skills in a way close to reality, which has made it possible to improve the degree of knowledge of the commercial operations of the companies in the sector but, above all, of the accounting technique (SiL) and more than $85 \%$ have seen an activity in the role play useful, which complements other types of tools in the learning process of the subject and allows students to develop social skills and collaborative work that, perhaps, with other more traditional methodologies, it would be more difficult to put into practice (DS).

On the other hand, in the comparison between groups, whereas between the different age groups there are no great differences in the perception of the students in each factor and, in general, in the level of satisfaction with the game, there seem to be differences when the analysis is carried out confronting the student body by gender. A priori, everything seems to indicate that, in general, although women have considered the game as a satisfactory experience for their learning and acquisition of skills, their perception is lower than that of men, who are very satisfied. 
Table 3

Description of the questionnaire

Sexes and age groups

\begin{tabular}{|c|c|c|c|c|c|c|c|c|c|c|c|c|}
\hline & \multicolumn{4}{|c|}{ By sex } & \multicolumn{8}{|c|}{ By age groups } \\
\hline & \multicolumn{2}{|c|}{ Man } & \multicolumn{2}{|c|}{ Woman } & \multicolumn{2}{|c|}{ E1 } & \multicolumn{2}{|c|}{ E2 } & \multicolumn{2}{|c|}{ E3 } & \multicolumn{2}{|c|}{ E4 } \\
\hline & Mean & $\begin{array}{l}\text { Stan. } \\
\text { dev. }\end{array}$ & Mean & $\begin{array}{l}\text { Stan. } \\
\text { dev. }\end{array}$ & Mean & $\begin{array}{l}\text { Stan. } \\
\text { dev. }\end{array}$ & Mean & $\begin{array}{l}\text { Stan. } \\
\text { dev. }\end{array}$ & Mean & $\begin{array}{c}\text { Stan. } \\
\text { dev. }\end{array}$ & Mean & $\begin{array}{c}\text { Stan. } \\
\text { dev. }\end{array}$ \\
\hline SiL & 4.35 & 0.240 & 3.47 & 0.936 & 3.84 & 0.519 & 4.16 & 0.344 & 4.75 & . & 3.03 & 1.254 \\
\hline SeL & 3.96 & 0.139 & 3.15 & 1.062 & 3.50 & 0.714 & 3.25 & 1.236 & 4.00 & . & 3.23 & 1.278 \\
\hline DS & 4.44 & 0.328 & 4.07 & 0.850 & 4.26 & 0.870 & 4.40 & 0.283 & 4.60 & . & 3.80 & 0.860 \\
\hline VT & 4.20 & 0.505 & 3.22 & 0.783 & 3.62 & 1.026 & 3.58 & 0.739 & 3.67 & & 3.27 & 0.830 \\
\hline$S$ & 4.00 & 0.70 & 3 & 0.85 & 3.29 & 0.75 & 3.25 & 0.50 & 3 & . & 3.40 & 1.51 \\
\hline
\end{tabular}

Source: Prepared by authors

Table 4 shows the results of the Anova analysis by which we verify whether the mean of each main component and of the dependent variable "Student satisfaction (S)" significantly differ, or not, between men and women and between students of the four age groups. We have rejected the null hypothesis of equality of means with a $95 \%$ confidence interval in all those components that reach a $p$-value $<0.05$. In the case of statistically significant differences arising from the Anova test for the different age groups, it has been corroborated with the Post Hoc analysis of Tukey HDS (Honestly-significant-difference) in which we have compared the value of each variable of two groups in two groups to verify if the cases in which the null hypothesis of equality of means has been rejected affects all age pairs or only some.

Table 4

Hypothesis testing and analysis of variance Anova (Between sex and between age groups)

\begin{tabular}{|c|c|c|c|c|}
\hline & \multicolumn{2}{|c|}{ By sex } & \multicolumn{2}{c|}{ By age groups } \\
\hline & F & Sig & F & Sig \\
\hline Situated Learning (SiL) & 4.160 & .059 & 2.315 & .124 \\
\hline Self-learning (SeL) & 3.287 & .090 & .135 & .937 \\
\hline Didactic Strategies (DS) & .732 & .406 & .635 & .606 \\
\hline Vocational Training (VT) & 6.296 & .024 & .176 & .911 \\
\hline Satisfacción (S) & 5.294 & .036 & .049 & .985 \\
\hline
\end{tabular}

Source: Prepared by authors

Considering the $\mathrm{F}$ statistic and the $\mathrm{p}$-value arising from the Anova analysis we can see that there are only statistically significant changes when the results are seen between men and women and only for the case of the factor that refers to the characteristics of the game related to skills related to vocational training, which also leads to significant differences between men and women for "Student satisfaction (S)", achieved with role playing; Although, in general, both men and women positively value the experience lived with role-playing, men achieve a higher level of satisfaction than women.

In order to get to know an explanatory model on the factors that influence the level of satisfaction of the students with the experience, a Multiple Linear Regression was developed and Table 5 shows the ability of the main components to explain the level of satisfaction that the students have shown by the experience. 
Table 5

Weight of the most influential coefficients

in the level of satisfaction

\begin{tabular}{|c|c|c|c|c|c|c|c|}
\hline Model (4). & $\begin{array}{c}\text { Coef. Est. } \\
\text { Beta }\end{array}$ & $\mathrm{t}$ & Sig. & $\begin{array}{c}\text { Sig of the } \\
\text { regression }\end{array}$ & Square R & $\begin{array}{c}\text { Adjusted } \\
\text { Square R }\end{array}$ & D-W \\
\cline { 1 - 4 } (Constant) & & 0.287 & .777 & 0.000 & 0.588 & 0.561 & 2.41 \\
\hline C4_VocationalTraining & .767 & 4.631 & .000 & 0.000 & & \\
\hline \multicolumn{7}{|c|}{ Source: Prepared by authors }
\end{tabular}

The method used is a regression model that performs a selection of explanatory variables "backwards" 4 consecutive times: Multiple Linear Regression Model 4 (RLM4). At the end of the variable selection process, those variables that maintained a significance level greater than 0.05 were excluded as explanatory factors of the level of satisfaction; that is, Situated Learning (C1), Self-Learning (C2) and Didactic Strategies (C3). On the contrary, Vocational Training (C4) shows a high influence capacity (Sig <0.05). The "Regression Model 4 " is the one that best shows the evolution of the level of student satisfaction, since it can explain $58.8 \%$ of the variability of satisfaction, in addition, it is the most consistent as it offers a significance of the regression of zero.

Mathematically it is defined as follows (2):

$S_{i}=\alpha+\beta_{4} F P_{i j}+\varepsilon$

and substituting the values of $\beta$ in (2) we would have (3)

$\mathrm{S}_{\mathrm{i}}=\alpha+0,767 \mathrm{FP} \mathrm{P}_{\mathrm{ij}}+\varepsilon$

From which it follows that the level of student satisfaction (S) is positively influenced by the variables grouped in the factor "Vocational Training (VT)". In other words, the greater the perception of the students that role-playing has allowed them to improve their ability to express and synthesize the economic and financial information of companies, as well as that with experience they have been able to apply their knowledge to the real professional world, the higher their level of satisfaction with the game. An increase of one percentage unit in the perception that students have about their Vocational Training process will lead to an increase of 0.767 points in the level of satisfaction with the game.

\subsection{Influence of role-playing on academic achievement}

For the analysis of "Academic achievement $(A A)$ ", we consider the results obtained by the students, both the control group and the experimental group, in the application of the pretest and post-test. The descriptive results of the evaluation are presented in Table 6.

Table 6

Description of the evaluation results before and after the role play

\begin{tabular}{|c|c|c|c|c|}
\hline & Group & Mean & Deviation & N \\
\hline \multirow{3}{*}{ Pretest } & Control & 2.01 & 2.063 & 78 \\
\cline { 2 - 5 } & Experimental & 2.89 & 2.484 & 29 \\
\cline { 2 - 5 } & Total & 2.25 & 2.208 & 107 \\
\hline \multirow{3}{*}{ Post-test } & Control & 1.70 & 2.202 & 78 \\
\cline { 2 - 5 } & Experimental & 3.37 & 2.563 & 29 \\
\cline { 2 - 5 } & Total & 2.15 & 2.411 & 107 \\
\hline
\end{tabular}

Source: Prepared by authors 
A priori, it can be observed that the evaluation results of the students who did not perform the role play do not differ between before and after the activity. But, in the case of the group that performed the role play, after the experience, it showed results that, although on average it did not reach the minimum passing level (5), they were better than the results they had obtained in the pretest, but, above all, they were better than those obtained by their classmates who did not perform the role play. This could be confirmed with the mixed Within-Between inviduals analysis, the results of which are summarized in Table 7.

Table 7

Univariate analysis Anova

Between-Within individuals

\begin{tabular}{|c|c|c|c|c|c|c|}
\hline Origin & $\begin{array}{c}\text { Sum of } \\
\text { Squares }\end{array}$ & $\mathrm{gl}$ & $\mathrm{F}$ & Sig $(\mathrm{p})$ & $\begin{array}{c}\text { Eta partial } \\
\text { square }(\mathrm{n} 2)\end{array}$ & Power \\
\hline Within & .298 & 1 & .208 & .649 & .002 & .074 \\
\hline Within*Between & 6.506 & 1 & 4.546 & 0.03 & .042 & .561 \\
\hline Within error & 150.258 & 105 & & & & \\
\hline Between & 69.106 & 1 & 7.994 & 0.006 & .071 & .80 \\
\hline Between error & 907.694 & 105 & & & & \\
\hline
\end{tabular}

Table 7 collects the information necessary to contrast the null hypothesis that there have been no differences in the results of the two groups before and after the role play. Based on the critical levels $(\mathrm{Sig}<0.05)$ and the $\mathrm{F}$ statistic, we reject the null hypothesis. There are statistically significant differences in the results of the students of the control group and the experimental group, according to the influence of the role play developed.

\section{Discussion and conclusions}

Returning to the general objective of the research, to determine the effects of the application of a role-playing game in the subject of Financial Accounting in the Degree in Tourism, and in accordance with the specific objectives defined around student satisfaction and academic achievement, we can make some appreciations that are of interest.

In the first place, in relation to the analysis of the satisfaction of the experimental group with respect to the role play proposal, we can state that, in general terms, the participants are satisfied or quite satisfied with the proposal, with results above the media in its consideration as a didactic strategy. These results are presented in line with previous studies that indicate better scores in the variables related to motivation, creativity, or collaboration (Moreno-Guerrero et al., 2020). In the analysis of the same variable, differences are shown between the groups according to sex, with the perception of satisfaction being higher in men than in women in general terms, although the differences are only statistically significant in the case of the dimension associated with vocational training.

Precisely, once the regression was carried out for the constituent dimensions of "Student satisfaction (S)", "Vocational Training (VT)" is presented as the most influential factor in the degree of satisfaction of the participants. The idea of evaluating a strategy according to its degree of application to work practice is not new; In fact, empirical studies, carried out in contexts similar to that of this research, present evidence of the contribution of role play to the business environment, observing that $100 \%$ of students consider role play as a useful tool for effective entrepreneurship and business practice associated with the labour market (Normando et al., 2020). 
Second, an improvement is observed in the academic achievement of those students who have worked on the content from the role play. Thus, the results of the students in the control group and the experimental group show statistically significant differences. In this regard, and despite the scarcity of studies, approaches in relation to marketing (Thanasi-Boçe, 2020) or accounting practices (Ros \& Conesa, 2013), not to mention academic achievement, have provided evidence in relation to the improvement of business skills and with general and specific skills in the accounting area.

In conclusion, the results of the study could be synthesized in a positive contribution of the application of the role play to the Accounting subject, both from the point of view of the students' perception and their level of satisfaction, and from the perspective of academic achievement; in line with the benefits that role-playing has presented in other areas of research and for solving social problems.

The application of this study has been carried out with a single experimental group and a control group. Considering the singularities of any group of students, and the individual and academic course factors that may condition the results, it is of interest to expand the research participants, considering the application of the instruments in different university contexts. In the same vein, a more analytical study could be carried out in relation to academic achievement, attending to comparisons according to the specific skills involved in achievement. Likewise, a study of correlations between the level of satisfaction and achievement, which are not the object of work, could be of interest.

\section{Bibliographic references}

Abella, V., \& Grande, M. (2010). Juegos de rol como estrategia educativa: percepciones de docentes en formación y estudiantes de secundaria. TESI: Teoría de la Educación. Educación y Cultura en la Sociedad de la información, 11(3), 27-54. DOI: 10.14201/eks.7449

Agencia Nacional de Evaluación de la Calidad y Acreditación (ANECA). Libro Blanco. Título de Grado en Turismo. Madrid: Publicaciones ANECA.

Axelrod, R. (1997). Advancing the Art of Simulation in the Social Sciences. In R. Conte, R. Hegselmann, \& Terna, P. (Eds.), Simulating Social Phenomena (pp. 21-40). Berlin: Springer.

Barrera, F., Venegas-Muggli, J.I., \& Nuñez, O. (2020) The impact of role-playing simulation activities on higher education students' academic results. Innovations in Education and Teaching Internacional. DOI: 10.1080/14703297.2020.1740101

Bollen, K.A. (1989). Structural equations with latent variables. New York: Wiley.

Bruner, J.S. (1969). Hacia una teoría de la instrucción. México DF: UTEHA.

Cerdá, L.M., \& Ramírez, M. (2010). Evaluación de estilos de liderazgo en la docencia: una aplicación en la enseñanza universitaria de postgrado. Sistemas, cibernética e informática, 7(1), 55-62. Retrieved from: http://www.iiisci.org/journal/CV\%24/risci/pdfs/MJ767WU.pdf

Clark, D.B., Tanner-Smith, E.E., \& Killingsworth, S.S. (2016). Digital games, design, and learning: A systematic review and meta-analysis. Review of Educational Research, 86(1), 79-112. DOI:

$10.3102 \% 2 F 0034654315582065$

De Miguel, M. (2006). Modalidades de enseñanza centradas en el desarrollo de competencias. Orientaciones para promover el cambio metodológico en el Espacio Europeo de Educación Superior. Oviedo:

Publicaciones Universidad de Oviedo. 
De Urbina, M., Medina, S., \& De la Calle, C. (2010). Herramientas para el aprendizaje colaborativo: una aplicación práctica del juego de rol. TESI: Teoría de la Educación. Educación y Cultura en la Sociedad de la información, 11(3), 277-300. Retrieved from:

https://revistas.usal.es/index.php/eks/article/view/7463/7479

Escobar, B., \& Lobo, A. (2005). Juegos de simulación empresarial como herramienta docente para la adaptación al Espacio Europeo de Educación Superior: experiencia en la Diplomatura en Turismo. Cuadernos de Turismo, 16, 85-114. Retrieved from: https://revistas.um.es/turismo/article/view/18381/17741

Ferrer, J., Ringer, A., Saville, K., Parris, M., \& Kashi, K. (2020) Students' motivation and engagement in higher education: the importance of attitude to online learning. Higher Education. DOI: 10.1007/s10734-02000657-5

Galvis, R.V. (2007). De un perfil docente tradicional a un perfil docente basado en competencias. Acción Pedagógica, 16(1), 48-57. Retrieved from:

http://www.saber.ula.ve/bitstream/handle/123456789/17284/articulo5.pdf;jsessionid=6599496582E64F1 EC9D18E5758541A33?sequence $=2$

García, M. (2009). La contabilidad como sistema de información y lenguaje común de los negocios. In V. Montesinos (Ed.), Introducción a la contabilidad financiera. Un enfoque internacional (pp. 29-37). Barcelona: Ariel. Economía.

Gómez, C., Ortuño, J., \& Miralles, P. (2018). Enseñar ciencias sociales con métodos activos de aprendizaje. Reflexiones y propuestas a través de la indagación. Barcelona: Octaedro.

Hacer, J.W. (1960). Business games. A simulation tecnique. lowa: State University of lowa.

Inda, M., Álvarez, S., \& Álvarez, R. (2008) Métodos de evaluación en la enseñanza superior. Revista de Investigación Educativa, 26(2), 539-552. Retrieved from:

https://revistas.um.es/rie/article/view/94061/90671

Johnson, L., Adams, S., Estrada, V., \& Freeman, A. (2014). NMC HorizonReport: 2014 Higher Education Edition. Austin, Texas: The New Media Consor-tiuM. http://cdn.nmc.org/media/2014-nmc-horizon-report-he-ENSC.pdf Accessed 7 December 2020.

Johnson, D.W., \& Johnson, R.T. (2018). Cooperative Learning: The Foundation for Active Learning. In S.M. Brito SM (Ed.), Active Learning- Beyond the Future. DOI: 10.5772/intechopen.81086

Johnson, D.W., Johnson, R.T., \& Holubec, E.J. (2013). Cooperation in the Classroom. Edina, MN: Interaction Book Company.

Johnson, D.W., Johnson, R.T., \& Smith, K.A. (2014). Cooperative learning: Improving university instruction by basing practice on validated theory. Journal on Excellence in College Teaching, 25(3-4), 85-118.

Jolliffe, I.T. (2002). Principal component analysis (2nd ed.). New York: Springer Series in Statistics.

Kapp, K.M. (2012). The gamification of learning and instruction: Game-based methods and strategies for training and education. Nueva Jersey: John Wiley \& Sons.

Kelleci, O., \& Aksoy, N.C. (2020). Using Game-Based Virtual Classroom Simulation in Teacher Training: User Experience Research. Simulation \& Gaming. DOI: 10.1177/1046878120962152 
Lave, J., \& Wenger, E. (1991). Situated learning. Legitimate peripheral participation. Cambridge: Cambridge University Press.

Lindquist, E.F. (1953). Design and analysis of experiments in psychology and education. Boston, MA: Houghton Mifflin.

Marcelo, C., Yot, C., Mayor, C. (2015). Enseñar con tecnologías digitales en la Universidad. Comunicar, 45(23), 117-124. DOI: 10.3916/C45-2015-12

McCrudden, M.T., Magliano, J.P., \& Schraw, G. (2010). Exploring how relevance instructions affect personal reading intentions, reading goals and text processing: A mixed methods study. Contemporary Educational Psychology, 35(4), 229-241.

Mora, A., Calabor, M.S., \& Moya, S. (2018). Adquisición de competencias a través de juegos serios en el área contable: un análisis empírico. Revista de Contabilidad-Spanish Accounting Review, 21(1), 38-47. DOI: 10.1016/j.rcsar.2016.11.001

Morales, R., \& Villa, C. (2019). Juegos de rol para la enseñanza de las matemáticas. Education in the Knowledge Society, 20, 1-13. DOI: 10.14201/eks2019_20_a7

Moreno-Guerrero, A.J., Rodríguez-Jiménez, C., Gómez-García, G., \& Ramos, M. (2020). Educational Innovation in Higher Education: Use of Role playing and Educational Video in Future Teachers' Training. Sustainability, 12 (2558). DOI: 10.3390/su12062558

Muñoz, C., \& Huser, A. (2008). Experiential and Cooperative Learning: Using a Situation Analysis Project in Principles Marketing. Journal of Education for Business, 83(4), 214-220.

Niemeyer, B. (2004). Situated learning for social and vocational integration in Germany. In K. Evans \& B. Niemeyer (Eds.), Reconnection: Countering social Exclusion Through Situated Learning (pp. 47-62). New York: Springer.

Normando, L., Barbosa, C.A., Reis, J., Almeida, A.E., \& Pereira, D. (2020). Inovação e Educação Empreendedora com o Modelo do Role play no Ensino Superior. Gestão, Inovação e Tecnologias, 10(3), 5505-5516. DOI: 10.7198/geintec.v10i3.1448

Oberle, M., Leuning, J., \& Ivens, S. (2020). What do students learn from political simulation games? A mixedmethod approach exploring the relation between conceptual and attitudinal changes. European Political Science, 19, 367-386. DOI: 10.1057/s41304-020-00261-2

Ortiz, D. (2015). El constructivismo como teoría y método de enseñanza. Sophia: colección de Filosofía de la Educación, 19(2), 93-110. Retrieved from: https://www.redalyc.org/pdf/4418/441846096005.pdf

Pérez, C., \& Santín, D. (2008). Minería de datos. Técnicas y herramientas. Madrid: Paraninfo.

Prensky, M. (2001). Digital Natives, Digital Immigrants. On the Horizon, 9(5), 1-6.

Rodríguez, J.M. (1975). Juegos de empresa. Madrid: ESIC.

Rooney-Varga, J.N., Sterman, J.D., Fracassi, E., Franck, T., Kapmeier, F., Kurker, V., Johnston, E., Jones, A.P., \& Rath, K. (2018). Combining role play with interactive simulation to motivate informed climate action: Evidence from the World Climate simulation. PloS ONE, 13(8). DOI: 10.1371/journal.pone.0202877

Ros, M.I., \& Conesa, M.C. (2013). Adquisición de competencias a través de la simulación y juego de rol en el área contable. Estudios sobre Mensaje Periodístico, 19, 419-428. 
Santiago, R., \& Fonseca, C.D. (2016). Ser buen profesor, una mirada desde dentro. EDETANIA, 50, 191-208. Retrieved from: https://revistas.ucv.es/index.php/Edetania/article/view/27/26

Schützemberger, A. (1979). Introducción al role playing. El sicodrama, el psicodrama y sus aplicaciones en asistencia social, en las empresas, en la educación y en psicoterapia. Madrid: Marova.

Son, S., Kang, A.R., Kim, H., Kwon, T., Park, J., \& Kim, H.K. (2012). Analysis of Context Dependence in Social Interaction Network of a Massively Multiplayer Online Role playing Game. PloS ONE, 7(4). DOI: 10.1371/journal.pone.0033918

Thanasi-Boçe, M. (2020). Enhancing students' entrepreneurial capacity through marketing simulations games. Education + Training, 62(9), 999-1013. DOI: 10.1108/ET-06-2019-0109

Urquidi, A.C., \& Calabor, M.S. (2014). Aprendizaje a través de juegos de simulación: un estudio de los factores que determinan su eficacia pedagógica. EDUTEC. Revista Electrónica de Tecnología Educativa, 47. Retrieved from: https://www.edutec.es/revista/index.php/edutec-e/article/view/75/pdf_6

Viñals, A., \& Cuenca, J. (2016). El rol del docente en la era digital. Revista Interuniversitaria de Formación del Profesorado, 30(2), 103-114. Retrieved from: https://www.redalyc.org/pdf/274/27447325008.pdf

Wouters, P., Van Nimwegen, C., Van Oostendorp, H., \& Van Der Spek, E. (2013). A Meta-Analysis of the Cognitive and Motivational Effects of Serious Games. Journal of Educational Psychology, 105(2), 249-265. DOI: $10.1037 / \mathrm{a} 0031311$

Yasnitsky, A., Van der Veer, R., Aguilar, E., \& García, L.N. (2016). Vygotski revisitado: una historia crítica de su contexto y legado. Buenos Aires: Miño y Dávila Editores.

Zumaquero, L. (2018). Los juegos de rol como estrategia de enseñanza-aprendizaje para fomentar la adquisición de competencias en la Titulación de Grado en Turismo. REJIE Nueva é poca: Revista Jurídica de Investigación e Innovación Educativa, 18, 43-56. DOI: 10.24310/REJIE.2018.v0i18.5056

Esta obra está bajo una Licencia Creative Commons Attribución-NoCommercial 4.0 International

\section{(c) EY-NC}

